\title{
The effectiveness of using educational cinema techniques to increase students' self-confidence: An experimental research
}

\author{
Prio Utomo* \\ Universitas Islam Negeri Fatmawati Sukarno Bengkulu \\ Sepakat St 15. Kee. Sawah Lebar Baru, Kota Bengkulu, Indonesia \\ E-mail: prio.um1990@gmail.com \\ Mar'atus Sholihah \\ Universitas Negeri Malang \\ Semarang St, 5, Malang City, Jawa Timur, Indonesia \\ E-mail: sholikhahmaratus18@gmail.com
}

Received: June 04, 2021; Revised: June 19, 2021; Accepted: July 27, 2021

\begin{abstract}
This research is motivated by the problem of low self-confidence of students. The purpose of this study was to test the effectiveness of educational cinema techniques as a medium to increase students' low self-esteem. The research design used pre experimental research with one group pretest and posttest design. The research subjects were 16 students of class VIII SMPN 6 Malang, the subjects were selected using purposive sampling technique. Data collection used (1) self-confidence scale; (2) experimental guidelines and (3) observation guidelines. Data analysis used descriptive and statistical analysis (Wilcoxon signed rank test). The results of data analysis produce that $\mathrm{H}_{0}$ is rejected and $\mathrm{H}_{1}$ is accepted, this means that there is a significant increase in student self-confidence after being given educational cinema techniques. The findings of the study show that there are differences in the improvement of students 'self-confidence between before (pretest) and after (posttest) being given educational cinema techniques, thus the results of the study concluded that educational cinema techniques were effective in increasing students' self-confidence.
\end{abstract}

Keywords: educational cinema technique, self-confidence, students

This is an open-access article under the CC-BY-SA license.

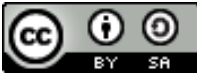

\section{Introduction}

The phenomenon of cheating is often done when the behavior during the exam, even worse cheating is done in the national exam. The phenomenon of cheating behavior has become a culture among students at school, they do not think about the long-term consequences resulting from this behavior. Cheating is a form of how they overcome problems that students are unable to solve, students lack self-confidence in their abilities as the main motive for cheating. The results of Irwawati research (Andiwatir \& Khakim, 2019) was showed that 59\% of students cheated, with $41 \%$ of students classified as individualistic-opportunistic cheating behavior, $27 \%$ belonging to individualistic plans, $16 \%$ of students belonging to socially active, and $14 \%$ belonging to social-passive. If the cause is observed, one of the factors causing students' cheating behavior is due to internal factors, namely low student self-confidence. The higher the student's 
self-confidence level, the higher the student's self-confidence in doing their schoolwork. Conversely, students with low self-confidence, then they tend to negative behaviors such as cheating.

The question is why students' self-confidence is low and what causes it? Problems that often arise and become the causative factor are internal factors such as low self-confidence in what they have in themselves, students have not been able to find their identity (identity) which then causes delays in their developmental tasks. The results of research by (Yudhianto, 2012) concluded that the problems experienced by junior high school students such as lack of selfconfidence because of body shape, feeling inferior because of poor family backgrounds, environmental conditions and so on. When viewed from their behavior, the behavior of students' low self-confidence is reflected as they cannot express their opinions during class discussions, are inferior, afraid, only have a few friends, rarely gather with their peers and only certain friends. As a result, the behavior of these students inhibits adjustment to adapt to the surrounding environment.

Basically, there are other factors that cause low student self-confidence, namely external factors such as criticism from parents and association with the environment such as peers group. (Hurlock, 2006) emphasized that children who were previously self-confident, in adolescence lose self-confidence and are afraid of failure due to a lot of criticism from parents and association with the environment (peers group). The function of the family in reducing the negative behavior of children is very decisive, meaning that the increasing social functioning of a family in carrying out life tasks, roles and functions, the lower the negative behavior of their children (Fatchurahman \& Pratikno, 2012).

Self-confidence is an individual's belief in his ability to be able to do a task or job that is shown in a positive attitude, namely being brave to act and be responsible. According to (Lautser, 2001) self-confidence is an attitude or belief in one's own abilities. So, in taking actions, they are not too anxious, feel burdened to do things according to their wishes and are responsible for their actions, are polite in interacting with others, have an achievement drive and know their own strengths and weaknesses. Another definition according to (Surya, 2007) says self-confidence is a mental attitude of optimism from the ability and ability to get things done and the ability to adapt to the situation at hand.

Student self-confidence is formed and influenced by several aspects, (Lautser, 2001) explains that there are several aspects of self-confidence including (1) Belief in self-ability, namely a person's positive attitude about himself that he really understands what he is doing; (2) Optimism, namely the positive attitude of someone who always has a good opinion in dealing with everything about himself, his hopes and abilities; (3) Objective, namely people who are selfconfident in seeing problems or everything; (4) something according to the proper truth, not according to personal truth; (5) Responsible, namely the willingness of a person to bear everything that has become the consequence; and (6) Rational, namely the analysis of a problem, a thing, an event by using thoughts that are accepted by reason and in accordance with reality.

Regarding the problem of low student self-confidence, having high self-confidence is very important, when students are based on high self-confidence, they are able and can well explore and develop their abilities. (Pradita, 2014) explains that self-confidence is important to participate in public life, as when joining a community that is involved in an activity or activity, selfconfidence increases the effectiveness of activities. (Aprianti, 2013) also explains that selfconfidence is the basic capital of success in all fields. The loss of self-confidence becomes something that is very disturbing, especially when faced with new challenges or situations. Adolescents who lack self-confidence will show that they tend to avoid new people or situations, are inferior, shy, anxious when in a crowd, close themselves off, avoid appearing in front of many people, are quiet, and other things that prevent someone from doing something.

In an effort to grow and increase students' self-confidence, one strategy that can be given to students in order to increase self-confidence is by training students to use symbolic modeling 
through educational cinema techniques. The basic assumption of consideration for the use of educational cinema through film media is that film is an audio-visual medium and can be used as a medium for student learning so that later they can increase students' enthusiasm for learning by imitating the characters in the film. In addition, films can be used as a fun learning medium, because students will be more interested in using audio-visual media in learning. Films are used as learning media for students because through films they can show a real picture of a problem.

Modeling is a learning process through observing the behavior of others as a model, so that there will be changes in new thoughts, attitudes, and behaviors. The model can be a real model (life model) and can also be a symbolic model. The real models are people such as counselors, teachers, or peers. Symbolic models can be presented through written materials such as cinema/film, audio and video recordings, slide recordings, or photographs. Symbolic modeling techniques can also be done by asking the counselee (student) to imagine someone doing the behavior that is the target as is done in covert modeling (Hidayah, 2014). The symbolic model used here in improving students is through symbolic modeling through educational cinema techniques, this technique is in the form of activities or learning processes carried out by students by watching films and reflecting the results of films that have been watched into themselves.

Modeling techniques as a means to facilitate change can increase student stimulus in learning. Modeling refers to the process through observing their thought patterns, beliefs and behavior after being displayed by one or more models (Hidayah, 2014). Modeling in educational cinema that is shown consists of two types, in the form of animated films and documentary films of a person's figure (character). (Yakar, 2018) classifies animated films as having a high attractiveness impact for research subjects, namely $24 \%$ compared to $6 \%$ for documentary films. Students show active attention when animated films are shown because there are many funny character models that get their attention compared to documentary films whose characters are monotonous and boring.

Educational cinema technique is the process of teaching students through the screening of educational cinema in the form of films where students are asked to reflect on themselves by imitating, following and imitating the behavior of the characters in the film. The use of educational cinema techniques through film screenings in an effort to increase students' selfconfidence is based on the fact that films create trends, have a huge influence on learning, and are a significant teaching method (Zaudere \& Ganzer, 2011). Through the screening of films, the contents of the stories and characters told can be used as models for students. According to (Arroio, 2007), during film performances, the content of the story is transmitted through various experiences such as: emotions, feelings, attitudes, actions, and knowledge. In other words, films can be a therapy for children and adolescents who need help with problems of motivation, selfconfidence, and self-assertive development (Soidhermer, 2000).

Strengthening the use of effective educational cinema techniques as a medium to increase students' self-confidence based on the results of previous studies conducted by (Jencius, 2011), (Hidayah, 2014), (Ragil et al., 2019), (Chambers \& College, 2019) proving that educational cinema techniques are effective and can be used as a medium to solve student problems. The conclusion of the research shows that educational cinema techniques are effective as a medium to overcome student problems, through the use of effective educational cinema techniques in this study will be used to find out how much effectiveness increases students' self-confidence, consideration of using this technique is based that educational cinema techniques are a treatment in the form the process of training students through showing educational cinema in the form of films, by watching films students will be asked to reflect on themselves by imitating, following and imitating the behavior of the characters in the film.

The purpose of this study was to test how effective the use of educational cinema techniques as a medium to increase students' self-confidence and how significant the increase in students' self-confidence was before and after being given educational cinema techniques. This study focuses on the problem of low student self-confidence and. The basis for choosing the 
problem of low self-confidence is suspected by one of the students' developments being influenced by the level of self-confidence. Students with high self-confidence will be active in their behavior, on the contrary, students with low self-confidence will be passive in their behavior and can lead to problems for themselves. The research hypothesis proposed is that there is an increase in students' self-confidence after being given educational cinema techniques.

\section{Method}

The research design used pre experimental research with one group pretest and posttest design. The research design was adapted from (Creswell, 2012); (Lodico et al., 2006); (Cohen et al., 2007). The design of this study was used to test the effectiveness of educational cinema techniques as a medium to increase students' self-confidence, the process of implementing this design includes a pretest (pretest) and a final test (posttest) then the results of the two tests are compared to find out changes in the subject (there is an increase the self-confidence). Students themselves after being given the cinema education technique).

The procedure for using educational cinema techniques through film media includes four stages consisting of (1) needs assessment, namely the process of knowing the problems and what students need so that later films can be selected; (2) Preparation, namely the process of preparing film media to be used as treatment materials; (3) Implementation, namely the process of showing/screening films according to a predetermined schedule; (4) Processing the experience, which is processing the student's experience after watching the film being shown, this process includes discussion, reflection and evaluation.

The implementation of the treatment of educational cinema techniques through film media was carried out in six meetings, including (1) the first meeting was a pretest; (2) the second meeting is treatment I (film screening and reflection); (3) The third meeting is treatment II (film screening and reflection); (4) The fourth meeting is treatment III (film screening and reflection); (5) The fifth meeting is treatment IV (film screening and reflection); and (6) The sixth meeting is the posttest.

This research was conducted at SMP Negeri 6 Malang. The research subjects were 16 students of class VIII with low self-confidence, the subjects were selected using purposive sampling technique. Data collecting using (1) self-confidence scale; (2) educational cinema technique guide and (3) observation guide. The validity of the instrument includes the validity of the educational cinema technique guide through expert judgment and the validity of the selfconfidence scale instrument through exploratory factor analysis of component principal analysis. This study uses nonparametric analysis, the analysis is used on the basis of the number of samples used in this study is small (16 students), so that the analysis process in this study does not test assumptions on the population (sample) tested whether it has a normal distribution and variety. Therefore, this study only uses distribution-free statistical analysis, namely the analysis process by not requiring the distribution of parameters from the population (sample) whether normal or not. Data analysis used the Wilcoxon signed rank test statistical analysis, the analysis was used to see how far the effectiveness of educational cinema techniques in increasing students' self-confidence by comparing the results of data from giving self-confidence scales before (pretest) and after (posttest) giving treatment through Wilcoxon signed rank test.

\section{Findings and Discussion}

The research data describes 1) the increase in students' self-confidence before (pretest) and after (posttest) given the educational cinema technique, 2) the score of increasing students' self-confidence after being given the educational cinema technique, and 3) the results of hypothesis testing. Based on the results of data analysis, it shows that there is an increase in 
students' self-confidence from the low category to the medium and high category after being given educational cinema techniques.

\section{Increasing Students' Self-confidence Before (Pretest) and After (Posttest) Given Educational Cinema Techniques}

After students were given the educational cinema technique, then the subject was given a posttest using a self-confidence scale to find out whether there was an increase in the increase in student self-confidence before and after being given the educational cinema technique. The increase in students' self-confidence is described in the following figure:

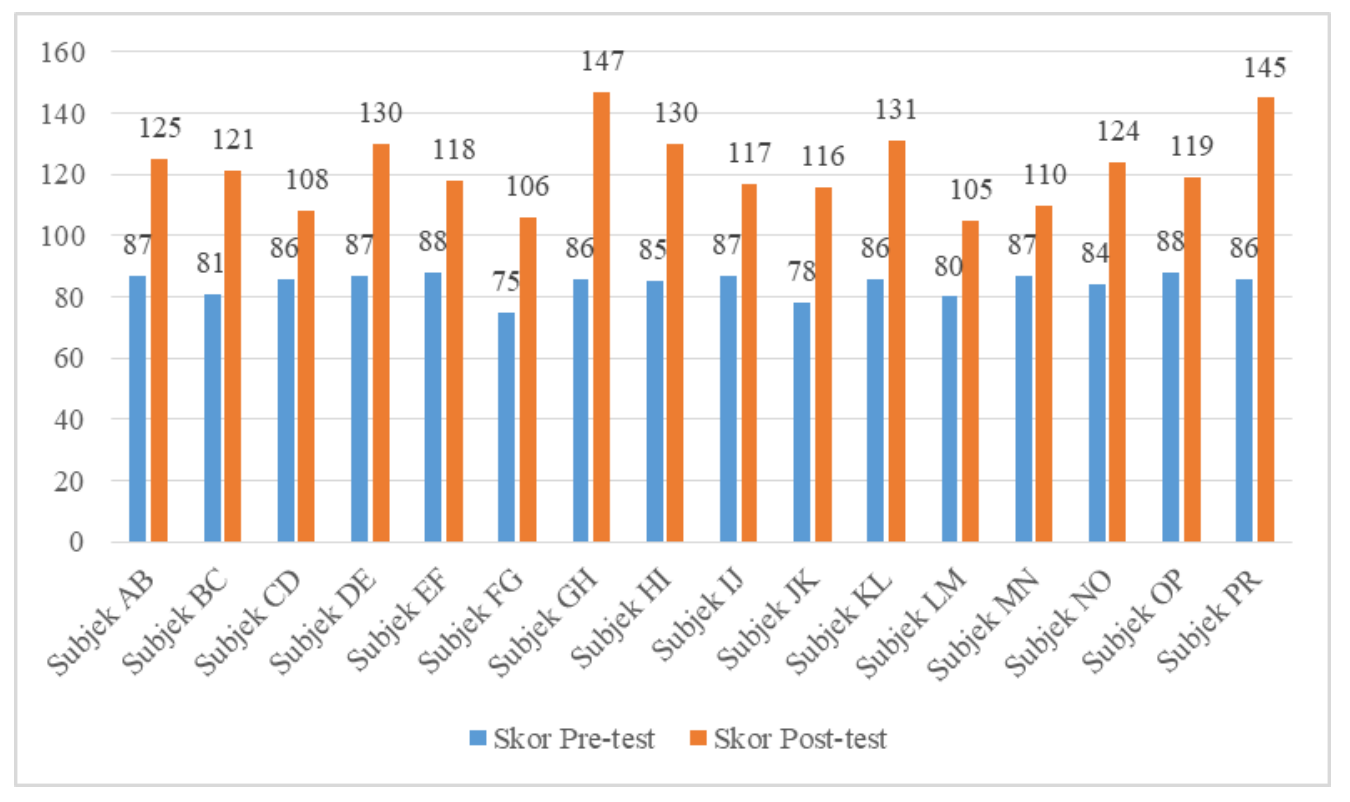

Figure 1. Graph of Increasing Student Self-confidence

Based on the graph above, it shows that all subjects experienced an increase in selfconfidence before (pretest) and after (posttest) given the educational cinema technique with the following details: 1) Subject AB's self-confidence score increased from low (87) to moderate (125); 2) self-confidence of BC subjects increased from low (81) to moderate (121); 3) CD subjects' self-confidence scores increased from low (86) to moderate (108); 4) the self-confidence score of ED subjects increased from low (87) to moderate (130); 5) EF subject's self-confidence score increased from low (88) to moderate (118); 6) the FG subject's self-confidence score increased from low (75) to moderate (106); 7) the GH subject's self-confidence ken score level increased from low (86) to high (147); 8) HI subjects' self-confidence scores increased from low (85) to moderate (130); 9) IJ subject's self-confidence score increased from low (87) to moderate (117); 10) JK subject's self-confidence level score increased from low (87) to moderate (116); 11) $\mathrm{KL}$ subject's self-confidence score increased from low (86) to moderate (131); 12) the LM subject's self-confidence score increased from low (80) to moderate (105); 13) the MN subject's self-confidence score increased from low (87) to moderate $(110) ; 14)$ the score of the NO subject's self-confidence level increased from low (84) to moderate (124); 15) the OP subject's self-confidence score increased from low (88) to moderate (119); 16) PR subjects' self-confidence scores increased from low (86) to moderate (145). These results indicate that there are 14 students who experienced an increase in self-confidence from low to moderate and as many as 2 students experienced an increase in self-confidence from low to high. 


\section{Score Increase in Students' Self-confidence After Being Given Educational Cinema Techniques}

Based on the results of the posttest, the findings show that students' self-confidence increase scores have different levels of increase between students. The difference in the increase in student scores is influenced by the ability of each student, but the results show an increase in student self-confidence scores in the same category, namely increasing in the medium and high categories. The score of increasing students' self-confidence is described in the following table:

Table 1. Increasing Score of Students' Self-confidence

\begin{tabular}{|c|c|c|c|c|c|}
\hline Subject & Pre-test Score & Category & $\begin{array}{c}\text { Post-test } \\
\text { Score }\end{array}$ & Category & $\begin{array}{c}\text { Increase } \\
\text { Score }\end{array}$ \\
\hline Subject AB & 87 & Low & 125 & Medium & 38 \\
\hline Subject BC & 81 & Low & 121 & Medium & 40 \\
\hline Subject CD & 86 & Low & 108 & Medium & 22 \\
\hline Subject DE & 87 & Low & 130 & Medium & 43 \\
\hline Subject EF & 88 & Low & 118 & Medium & 30 \\
\hline Subject FG & 75 & Low & 106 & Medium & 31 \\
\hline Subject $G H$ & 86 & Low & 147 & High & 61 \\
\hline Subject HI & 85 & Low & 130 & Medium & 45 \\
\hline Subject IJ & 87 & Low & 117 & Medium & 30 \\
\hline Subject JK & 78 & Low & 116 & Medium & 38 \\
\hline Subject KL & 86 & Low & 131 & Medium & 45 \\
\hline Subject LM & 80 & Low & 105 & Medium & 25 \\
\hline Subject $\mathrm{MN}$ & 87 & Low & 110 & Medium & 23 \\
\hline Subject NO & 84 & Low & 124 & Medium & 40 \\
\hline Subject OP & 88 & Low & 119 & Medium & 31 \\
\hline Subject PR & 86 & Low & 145 & High & 59 \\
\hline
\end{tabular}

Based on table 1.1 above, it shows that there is an increase in students' self-confidence after being given educational cinema techniques from the low category to medium and high categories. A total of fourteen subjects increased self-confidence from low to medium category and as many as two subjects increased self-confidence from low to high category. Based on the results of the recapitulation of students' self-confidence scores, the findings indicate that the provision of educational cinema techniques is effective in increasing students' self-confidence where the pretest results show students in the low category and after being given educational cinema techniques, the posttest results show an increase in each student's score.

\section{Research Hypothesis Testing}

To find out whether there are similarities between the results of the pretest and posttest of all students, the Wilcoxon test was carried out, the test was carried out with the aim of knowing the differences in students' self-confidence levels. Based on the Wilcoxon signed rank test on the level of students' self-confidence before and after being given the educational cinema technique, it shows that there is no similarity between the results of the pretest and posttest of all junior high school students. The results of the Wilcoxon signed rank test are described in the table below.

Table 2. Wilcoxon Signed Rank Test Results on Students' Self-confidence Levels

\begin{tabular}{llrrr}
\hline & & Ranks & \\
\hline \multirow{3}{*}{ Posttest- Pretest Score } & $\mathbf{N}$ & Mean Rank & Sum of Ranks \\
\cline { 3 - 5 } & Negative Ranks & $0^{\mathrm{a}}$ & .00 & .00 \\
& Positive Ranks & $17^{\mathrm{b}}$ & 9 & 153 \\
& Ties & $0^{\mathrm{c}}$ & & \\
& Total & 17 & & \\
\hline
\end{tabular}

Based on the results of the Wilcoxon Signed Rank Test on the posttest-pretest scores, it shows that the calculated negative rank value produces an $\mathrm{N}$ value of 0 , the mean rank value is 0.00 , and the sum of rank is 0.00 . The positive calculated value of rank produces an $\mathrm{N}$ value of 17 , the mean rank value is 9.00 , and the sum of rank is 153 . In the Ties count, the $\mathrm{N}$ value is 0 , 
this result indicates that there is no similarity between the pretest and posttest results for all junior high school students.

The purpose of this study was to test the effectiveness of using educational cinema techniques as a medium to increase students' self-confidence. To find out whether the educational cinema technique is effective in increasing students' self-confidence, then the research hypothesis is tested. Hypothesis testing was conducted to answer research questions. The hypotheses proposed in this study are:

$\mathrm{H}_{0}=$ there is no increase in students' self-confidence after being given educational cinema techniques.

$\mathrm{H}_{1}=$ there is an increase in students' self-confidence after being given educational cinema techniques.

Decision making on hypothesis testing with the provision that if the asimp sig 0.05 then $\mathrm{H}_{0}$ is rejected and $\mathrm{H}_{1}$ is accepted. The results of hypothesis testing are presented in the table below.

Table 3. Wilcoxon Signed Rank Test Results

\begin{tabular}{lr}
\hline & Posttest Score- Pretest Score \\
\hline$Z$ & $-3.622^{\mathrm{b}}$ \\
Asymp. Sig. (2-tailed) & .000 \\
\hline a. Wilcoxon Signed Ranks Test & \\
b. Based on negative ranks. &
\end{tabular}

Based on the results of the Wilcoxon Signed Ranks Test above, it shows that the calculation results produce a $Z$ value of -3.622 with a probability value of .000 (probability value $<0.05$ then $\mathrm{H}_{0}$ is rejected). The results show that $\mathrm{H}_{0}$ is rejected and $\mathrm{H}_{1}$ is accepted (F count asym. Sig. (2-tailed) $0.000<0.05$, then $\mathrm{H}_{0}$ is rejected) this means that there is an increase in students' self-confidence after being given educational cinema techniques. The conclusion of the research hypothesis is that there is an increase in students' self-confidence after being given the educational cinema technique, the findings show that before being given the educational cinema technique the pretest results showed students' self-confidence was in the low category and after being given the educational cinema technique the posttest results showed students' selfconfidence increased in the medium and high categories. . The conclusion of this study is that the technique of educational cinema is effective and can be used as a medium to increase students' self-confidence.

\section{Discussion}

Based on the results of the study, the findings indicate that there is an increase in students' self-confidence after being given the educational cinema technique, the increase in students' self-confidence can be seen before being given the educational cinema technique. The pretest results show that students' self-confidence is in the low category and after being given the educational cinema technique, the posttest results show students' self-confidence. Increased in the medium and high categories. The findings of this study were obtained based on (1) increasing students' self-confidence before (pretest) and after (posttest) being given the educational cinema technique. It showed that as many as 14 students experienced an increase in self-confidence from low to moderate and as many as 2 students experienced an increase in self-confidence from low to moderate, (2) the score of increasing students' self-confidence after being given the educational cinema technique, the findings of the pretest results showed that students' selfconfidence was in the low category and after being given the educational cinema technique the posttest results showed an increase in the self-confidence scores of each student, and (3) Research hypothesis testing shows the results of the calculation $h_{0}$ is rejected and $h_{1}$ is accepted, this means that there is an increase in students' self-confidence after being given educational cinema techniques.

The increase in students' self-confidence was also obtained from the results of observations and student self-reflection sheets, the findings showed that (1) In treatment I, 
students were able to recognize themselves after watching the film 'This Is Me' and were able to carry out the process of self-reflection; (2) In treatment II, students can motivate themselves after watching the movie 'The Billionare' and are able to carry out the process of self-reflection; (3) In treatment III, students can appreciate the films shown with different characters and are able to carry out different self-reflection processes (feelings of joy, sadness, humor, challenges); (4) In treatment IV, after watching the film, students can reflect on how to think positively. Overall self-reflection shows that they can analyze the factors that cause their low self-confidence, steps to overcome them, and efforts to shape positive behavior.

Other findings were also obtained from posttest results which showed as many as 14 students from the low category increased in the moderate category, and as many as 2 students from the low category increased in the high category. From the overall treatment implementation, the findings show that students can follow well and are able to follow the instructions taught in an effort to build and increase their self-confidence which includes aspects of (1) self-appearance skills, self-love; (2) formulating clear goals; (3) self-understanding, assertiveness, communication skills; and (4) positive thinking. The self-confidence that appears in students is obtained on average from watching movies which then inspires and raises students' self-confidence.

During the process of providing educational cinema techniques through film media, students were enthusiastic to watch the films that were shown. Film screening is not only for students to watch the film, but after watching it they are asked to discuss and draw the meaning of the content of the film they watch. In essence, educational cinema through film as a medium of learning cannot be separated from the current condition of students who are developing in a rapidly developing information technology culture. Films are also able to display information in the form of writing, images, animation, and sound so that students are more interested in participating in learning (Maharani et al., 2019). The purpose of the students being asked to discuss is to measure the extent to which they understand the message and content of the film being shown, and verbalize it to themselves and then apply it to themselves in their daily lives. In essence, film screening aims for students to take one of the characters from each scene that they do to be used as inspiration and imitate it. This means that educational cinema has a significant influence in making it easier for students to have problem solving skills (Nugraheni, 2004), one of which is the problem of low student self-confidence.

Educational cinema techniques through film media have a significant increase in students' self-confidence. The film used in this study is a film that contains indicators of self-confidence and inspires motivation. By watching films that contain elements of self-confidence, students can understand, formulate and overcome self-confidence problems. Other the findings show that after watching the film they can follow and learn from the experiences of the characters in the film to be applied in real life behavior in increasing self-confidence. By feeling yourself as a character in the film, it will make it easier for students to understand and apply the messages obtained in the film into their lives.

Increasing students' self-confidence by using educational cinema techniques through film media provides changes in students' results, this is because films are more interesting and not boring. (Munaji, 2008) explains that film is a communication tool that really helps the effective learning process. From what is seen by the eye and heard by the ear, it is faster and easier to remember than what can only be read or only heard. The effects of a film are very strong because the synergistic impact of music, dialogue, lighting, shooting angles, and sound effects allows the film to bypass the defensive sensors within a person. Movies can change students' attitudes by using parables, when students imagine themselves as characters in films, they will be inspired to imitate them in everyday life.

The use of educational cinema techniques as a medium to increase students' selfconfidence is a technique that uses film screenings as a tool or media in treatment, the content of the film has relevance and relevance to the problems experienced by students and can later be imitated with the aim of changing mind seat, feelings and behavior students are related to low 
self-confidence. In its meaningful role, (Wu, 2008) describes the effect of a film cinema as very strong because the synergistic impact of music, dialogue, lighting, shooting angle, and sound effects allows the film to pass through the defensive censorship in students. Meanwhile, the content of film stories can help develop students' awareness, disseminate information, and train students in health sciences and health professionals (Diez et al., 2005). Judging from the effect, the film offers a visual depiction in the form of a personal narrative, from the emotional aspect of health problems (Zauderer \& Ganzer, 2011). The use of educational cinema techniques is more practical, by watching films students can understand and follow (reflect) their attitudes to be able to follow the characters in the film's story, thus the characters in the film are models for students to imitate (follow). Educational cinema techniques through film media in the process use a cognitive-behavioral approach, this is based on the fact that the film contains elements of knowledge and self-understanding (cognitive) and action efforts to be able to perform (behavior) according to the characters played, besides the effects film can provide reflection on students so that it will be a bridge for students to grow and increase their self-confidence.

Judging from its effectiveness, educational cinema through screening films as bee films is meaningful to reflect on students' self (Blasco \& Moreto, 2012); (Oh et al., 2012), influencing cognition and attitudes (Brown et al., 2008); (Arroio, 2007) and stimulate self-awareness (Alexander \& Waxman, 2000). It can be concluded that educational cinema techniques through films can increase students' low self-confidence, this can be seen after watching the film they can understand and feel what is experienced by the characters in the film. (Wolz, 2004) says cinema in the form of films can be a powerful catalyst for healing and growth for anyone who is open to learning how films affect us and watching certain films with conscious awareness. In its functioning, the purpose of educational cinema is to heal and prevent self-confidence problems, through educational cinema (film) students can imitate the model played by the film's character. (Yakar, 2018) explains that the objectives that can be achieved in using cinema in learning have various aspects that support research, namely academic achievement, social development, and emotional development. Educational cinema through films is effective for increasing selfconfidence, this is based on watching films, it can indirectly affect cognitive, affective, psychomotor and stimulus aspects for students to be able to do what they see from the film.

\section{Conclusion}

Based on the results and discussion of the research, the research findings indicate that there is an increase in students' self-confidence before (pretest) and after (posttest) given the educational cinema technique. The increase in students' self-confidence can be seen before being given the educational cinema technique, the results of the pretest show that the students' selfconfidence is in the low category and after being given the educational cinema technique, the posttest results show that the students' self-confidence increases in the medium and high categories. Thus, it can be concluded that the use of educational cinema techniques is effective and can be used as a medium to increase students' self-confidence. With this, educational cinema techniques can be adopted as a treatment in solving the problem of low student self-confidence.

Recommendations and suggestions offered from the results of this study for further researchers include (1) the practical benefits of the results of this research can be used as reference material for teachers/school counselors in providing learning and services/guidance in schools; (2) Further researchers can consider the limitations of this study, namely the focus of the research subject is students who have low self-confidence; (3) The next researcher can consider the number/size of the research sample; (4) The next researcher can choose preventive action (prevention); (5) The next researcher considers the aspects and characteristics of the type of subject (other than junior high school students).

The implications of the results of this study that are offered for further research include (1) The results of this study can be used as a research novelty related to the use of educational 
cinema techniques; (2) educational cinema techniques can be used as a medium (treatment) to increase students' self-confidence, (3) the results of this study can be used as references and references related to efforts to overcome students' self-confidence problems through educational cinema techniques.

\section{References}

Alexander, M., \& Waxman, D. (2000). Cinemeducation: Teaching family Systems through the Movies. Families, Systems \& Health, 18(4), 455-466.

Andiwatir, A., \& Khakim, A. (2019). Analisis Perilaku Menyontek dan Rancangan Perubahannya pada Siswa SMP ( Analysis of Cheating Behavior and Change Design in Junior High School Students ) Info Artikel Abstrak Pendidikan sebagai sarana pembentuk intelektual dan moral diharapkan bebas dari b. Jurnal Psikologi Ilmiah, 11(2), 88-97.

Aprianti, R. (2013). Menumbubkan Kepercayaan Diri Melalui Kegiatan Bercerita. Indeks.

Arroio, A. (2007). The Role of Cinema Into Science Education. Problem of Education In The 21st Century, 1.

Blasco, P. G., \& Moreto, G. (2012). Teaching Empathy through Movies: Reaching Learners ' Affective Domain in Teaching Empathy through Movies: Reaching Learners 'Affective Domain in Medical Education. Journal of Education and Learning, 1(1). https://doi.org/10.5539/jel.v1n1p22

Brown, S., Kirkpatrick, M., Mangum, D., \& Avery, J. (2008). A Review of Narrative Pedagogy Strategies to Transform Traditional Nursing Education. Journal of Nursing Education, 479(2), 283-286.

Chambers, J., \& College, E. (2019). Exploring co-creation in practical film education from primary school to postgraduate study: Theoretical and auto-ethnographic perspectives upon teaching film practice. Film Education Journal, 2, 27-47.

Cohen, L., Manion, L., \& Morrison, K. (2007). Research Methods in Education. Sixth edition. Routledge Taylor \& Francis Group.

Creswell, J. W. (2012). Educational Research: Planning, Conducting, and Evaluating Quantitative and Qualitative Research (Fourth Edition). Pearson.

Diez, K., Pleban, F., \& Wood, R. (2005). Lights, Camera, Action: Integrating Popular Filmin the Health Classroom. Journal of School Health 72 (7), 72(7), 271-275.

Fatchurahman, M., \& Pratikno, H. (2012). Demokratis dan Kenakalan Remaja. Persona: Jurnal Psikologi Indonesia, 1(2).

Hidayah, N. (2014). Keefektifan Teknik Sinema Edukasi untuk Meningkatkan Sikap Asertif Siswa MTs Negeri Malang I. Jurnal Pendidikan Dan Pembelajaran, 21(2), 165-172.

Hurlock, E. (2006). Psikologi Perkembangan: Suatu Pendekatan Sepanjang Rentang Kebidupan. Erlangga.

Jencius, M. (2011). Movie Magic and Mental Health. Counselling Today Journal., 53, 11-22.

Lautser, P. (2001). Psikologi Kepribadian. PT. Bumi Aksara.

Lodico, M., Spaulding, D., \& Voegtle, K. (2006). Methods in Educational Research: From Theory to Practice. John Wiley \& Sons, Inc.

Maharani, I., Fridani, L., \& Akbar, Z. (2019). Efektifitas Penggunaan Media Film Bertema Layanan Informasi Bimbingan Klasikal. Jurnal Ilmiah Kependidikan, 6(2), 135-146.

Munaji, Y. (2008). Media pembelajaran sebuah pendekatan baru. Gunung Persada Press. 
Nugraheni, W. (2004). Efektivitas Cuplikan Sinema Edukasi Untuk Meningkatkan Keterampilan Pemecahan Masalah Bagi Siswa SMP. Jurnal Universitas Negeri Malang. JPPI. Jilid 6, Nomor 9.

Oh, J., Kang, J., \& De Gagne, J. (2012). Learning concepts of cinenurducation: an integrative review. Nurse Education Today, 32(8), 914-919.

Pradita, P. (2014). Stopminder dan Grogi: Saatnya Tampil Beda dan Percaya Diri. Araska.

Ragil, E., Ariyanto, R. D., Ratnawati, V., Ningsih, R., \& Valdino, D. R. (2019). Keefektifan Teknik Modeling Berbasis Sinema Edukasi untuk. Jurnal Nusantara of Research, 6(1), 50-59.

Soidhermer, A. (2000). The Life Stories of Children and Adolescents Using Commercial Films as Teaching Aids, Academic Psychiatry. University of Medicane.

Surya, H. (2007). Kepercayaaan Diri Itu Penting. Gramedia.

Wolz, B. (2004). E-motion Picture A Movie Lover's Guide To Healing and Transformation. Glenbridge Publishing Ltd.

Wu, A. (2008). Applying Cinema Therapy with Adolescent and a Cinema Therapy Workshop. California State University.

Yakar, H. G. (2018). Use of the Movies in the Turkish Language and Literature Education in Turkey. Journal of Education and Learning, 7(3), 41-55. https:// doi.org/10.5539/jel.v7n3p41

Yudhianto, A. (2012). Pengembangan Media Permainan Simulasi Peta Pemburu Bajak Laut Untuk Meningkatkan Kepercayaan Diri Siswa Kelas VII SMPNU Syamsuddin Malang. In Malang: Universitas Negeri Malang.

Zaudere, C., \& Ganzer, C. (2011). Cinematic Technology: the Role of Visual Learning. Nurse Educator, 36(2).

Zauderer, C., \& Ganzer, C. (2011). Cinematic Technology: the Role of Visual Learning. Nurse Educator, 36(2), 76-79. 